Scientia Marina 77(4)

December 2013, 641-647, Barcelona (Spain)

ISSN: 0214-8358

doi: 10.3989/scimar.03902.28C

\title{
Dusk but not dawn burrow emergence rhythms of Nephrops norvegicus (Crustacea: Decapoda)
}

\author{
VALERIO SBRAGAGLIA ${ }^{1,2}$, JACOPO AGUZZI ${ }^{1}$, JOSE ANTONIO GARCÍA ${ }^{1}$, \\ JUAN JOSE CHIESA ${ }^{3}$, CLAUDIO ANGELINI ${ }^{4}$ and FRANCESC SARDÀ ${ }^{1}$ \\ ${ }^{1}$ Institut de Ciències del Mar, CSIC, Passeig Marítim de la Barceloneta 37-49, 08003 Barcelona, Spain. \\ E-mail: sbragaglia@icm.csic.es \\ ${ }^{2}$ Coop. Cypraea scarl, V. Marco Enrico Bossi 1, 00124 Rome, Italy. \\ ${ }^{3}$ Laboratorio de Cronobiología, Departamento de Ciencia y Tecnología, Universidad Nacional de Quilmes - CONICET, \\ Roque Sáenz Peña 352, B1876BXD Bernal, Buenos Aires, Argentina. \\ ${ }^{4}$ via G. Marconi 30, 04018 Sezze, Italy.
}

SUMMARY: The Norway lobster, Nephrops norvegicus, can be captured by haul nets only during the emergence from its burrow. In the last few decades, an extensive field research revealed distinct diel (24-h-based) catchability patterns at different depths. Laboratory experiments suggested that burrow emergence (used as a proxy of catchability) is endogenously controlled via a circadian system. Results were usually presented in terms of mean effects without a quantification of interindividual variability and arrhythmia. Here, we studied the burrow emergence of 52 adult Nephrops by an infrared actograph endowed with an artificial burrow. Animals were exposed to 12-12 h light-darkness cycle, simulating photic condition of the lower shelf. Forty-five animals showed rhythmic emergence (87\%), while seven were arrhythmic (13\%). Rhythmic animals were clustered according to their timing of emergence: $54 \%$ at dusk and $4 \%$ at dawn. Moreover, other animals showed fully diurnal or nocturnal emergence (10\% and 19\%, respectively). The comparison of our results with those derived from temporally scheduled trawling indicates that bimodal catch patterns observed in shelf populations are poorly observed during individual experiments in the laboratory, where the same light conditions are simulated. Nephrops burrow emergence seems to be the result of a mixed endogenous-exogenous control, while arrhythmia could also be present in the wild.

Keywords: Nephrops norvegicus, circadian system, emergence behaviour, dusk and dawn, arrhythmia.

RESUMEN: Prevalencia del ritmo de emergencia al anochecer frente al amanecer en la Cigala NePHrops norvegicus (Crustacea: Decapoda). - La cigala, Nephrops norvegicus, es capturada con arte de arrastre cuando emerge de su madriguera. En las últimas décadas, una extensa investigación de campo ha revelado distintos patrones diarios (24-h) de capturas en diferentes profundidades. Se ha observado en experimentos de laboratorio que la emergencia desde la madriguera (interpretable como capturabilidad), está bajo el control endógeno de un sistema circadiano. En estos estudios los resultados se han presentado como efecto promedio en la población experimental, sin una cuantificación de la variabilidad inter individual o del porcentaje de arritmicidad. En este trabajo se estudió la actividad de emergencia desde la madriguera de Nephrops en 52 animales mediante un actógrafo de infrarrojos en un tanque dotado de una madriguera artificial, con un fotoperiodo de 12-12 luz-oscuridad, a fin de simular las condiciones fóticas de la plataforma marina. Cuarenta y cinco animales mostraron una emergencia rítmica (87\%), mientras que siete fueron arrítmicos (13\%). Los animales rítmicos fueron agrupados de acuerdo al momento de emergencia: $54 \%$ al "atardecer" y $4 \%$ al "amanecer", mientras que otros mostraron una emergencia totalmente diurna o nocturna (10\% y 19\%, respectivamente). La comparación de nuestros resultados con los datos procedentes de pescas experimentales de arrastre, indica que los patrones bimodales de captura observados en poblaciones de la plataforma, son pobremente reproducidos en laboratorio, donde se simulan las mismas condiciones fóticas del fondo marino. La emergencia de Nephrops desde la madriguera parece estar controlada por un proceso tanto endógeno como exógeno, mientras que la arritmicidad podría ser observada también en el campo.

Palabras clave: Nephrops norvegicus, sistema circadiano, comportamiento de emergencia, atardecer y amanecer, arritmia. 


\section{INTRODUCTION}

The Norway lobster, Nephrops norvegicus (Linnaeus, 1758), is a burrowing decapod that is a good model for biological rhythm research in marine organisms (Aguzzi and Sardà 2008). The behaviour of Nephrops can be inferred by temporally scheduled trawling because captures occur only when individuals are away from their burrows (i.e. "emergence behaviour", Main and Sangster 1985, Newland and Chapman 1989). Over the last few decades, extensive field research has revealed different diel $(24 \mathrm{~h})$ catchability patterns at different depths. On the upper continental shelf $(10-50 \mathrm{~m})$, captures are usually high at night, and emergence behaviour appears to be influenced by moonlight (Chapman and Rice 1971, Chapman et al. 1975, Chapman and Howard 1979). This pattern becomes crepuscular on the lower shelf (50-200 m), with bimodal dusk and dawn peaks of catches (Chapman et al. 1972, Farmer 1975). Finally, the pattern is fully diurnal on the upper slope (200-430 m) (Hillis 1971, Aguzzi et al. 2003). Therefore, it was hypothesized that the emergence behaviour of Nephrops is regulated in a bathymetry-dependent manner because the light intensities that trigger this behaviour occur at different times based on depth (Chapman et al. 1972).

To understand the emergence behaviour of shelf and slope populations, laboratory studies assessed the locomotor activity and burrow emergence of individuals in response to 24-h light-darkness regimes of different light intensities (e.g. Atkinson and Naylor 1976, Hammond and Naylor 1977, Aguzzi et al. 2004). These studies revealed that $N$. norvegicus activity was controlled not merely by optimum light intensity, as hypothesized by Chapman et al. (1972), but also by other unknown factors (Bell et al. 2006, Aguzzi and Sardà 2008, Katoh et al. 2013). Moreover, the presence of diurnal catchability in Mediterranean slope populations (Froglia 1972, Aguzzi et al. 2003) suggested that blue light (approx. 470-480 nm) might be the most effective trigger of burrow emergence (Aguzzi et al. 2009).

It is thought that Nephrops possesses a plastic circadian system composed of oscillators and that the degree of coupling between these oscillators generates burrow emergence rhythms with different timings between shelves and slopes (Aguzzi et al. 2011). This plasticity can be induced in the laboratory by applying light cycles at different intensities that simulate different depths (Chiesa et al. 2010). Laboratory tests have often reported inter-individual variability in emergence timing and also a proportion of arrhythmic individuals (i.e. ones not showing any significant peak in locomotor activity). However, these results have typically been presented in terms of mean effects on the sample under study, without a quantification of inter-individual variability. Moreover, the arrhythmia was usually attributed to the stress of laboratory captivity (Aguzzi et al. 2005). Our aim was to quantify the proportions of animals with different rhythmic burrow emergence patterns, including arrhythmia, under the light intensity regime that simulates the lower shelf photic environment. The results were compared with catch patterns in the same area from which the animals were obtained.

\section{MATERIALS AND METHODS}

Fifty-two intermoult adult $N$. norvegicus $(37$ males and 15 unberried females) with a mean carapace length $(\mathrm{CL} ; \mathrm{mm} \pm \mathrm{sd})$ of $37.87 \pm 4.97$ were sampled at nighttime at the end of September (autumn equinox) by a commercial trawler on the western Mediterranean shelf (approx. $100 \mathrm{~m}$ in depth) off the Ebro delta $\left(41^{\circ} 23^{\prime} 0^{\prime}\right.$ ', N; $2^{\circ} 11^{\prime} 0^{\prime}$ 'E). Deck operations were conducted under dim red light to avoid any potential damage to the animals' eyes (Gaten 1988; Gaten et al. 1990; Gaten et al. 2013). Specimens were immediately transferred to dark, refrigerated $\left(10 \pm 1^{\circ} \mathrm{C}\right)$ and aerated containers soon after hauling. Within these containers, individuals were housed separately in plastic bottles to prevent fighting that might result in bodily damage.

In the laboratory, all animals were acclimatized in individual cells $(25 \times 20 \times 30 \mathrm{~cm})$ within a collective tank inside an isolated chamber, under the following conditions: i) constant temperature of $13 \pm 0.5^{\circ} \mathrm{C}$ and 12-12 h light-darkness cycles (LD; on and off times at 07:00 and 19:00, respectively) of blue monochromatic light (480 nm) at 10 lux (light meter LX-1102, Lutron), comparable with the continental shelf photic conditions at autumn equinox (Aguzzi et al. 2003); and ii) random feeding times to prevent unpredictable effects of food entrainment on behaviour (Fernandéz de Miguel and Aréchiga 1994). Full light intensity was progressively attained (and extinguished) over $30 \mathrm{~min}$ to allow the animals' eyes to acclimate and thus avoid degeneration of the photoreceptors (Gaten et al. 1990). Blue light is present over the entire twilight depth range (Jerlov 1968) and likely entrains the diel rhythms of benthic decapods distributed on shelves and slopes (Aguzzi and Company 2010). This hypothesis is supported by the presence of blue light photoreceptors in crayfish (Fanjul-Moles et al. 2005) and the ubiquity of such receptors in the animal kingdom (Hankins et al. 2008).

We performed a total number of five replicate experiments. In each experiment, the lobsters were not fed for 11 days. Burrow emergence rhythms were measured with an infrared (IR) actograph (Aguzzi et al. 2008). We used individual aquaria endowed with burrows to discriminate the activity in relation to the burrow. To relate field catch patterns to locomotor activity in the laboratory, we considered only full excursion (i.e. animals clearly away from their burrow) as a proxy for emergence behaviour in the field that results in full catchability (Main and Sangster 1985, Newland and Chapman 1989) (Fig. 1). Blue monochromatic $(480 \mathrm{~nm})$ LEDs provided a light intensity cycle equal to the one imposed during acclimation (i.e. 12-12 h LD at $10 \operatorname{lux})$. 

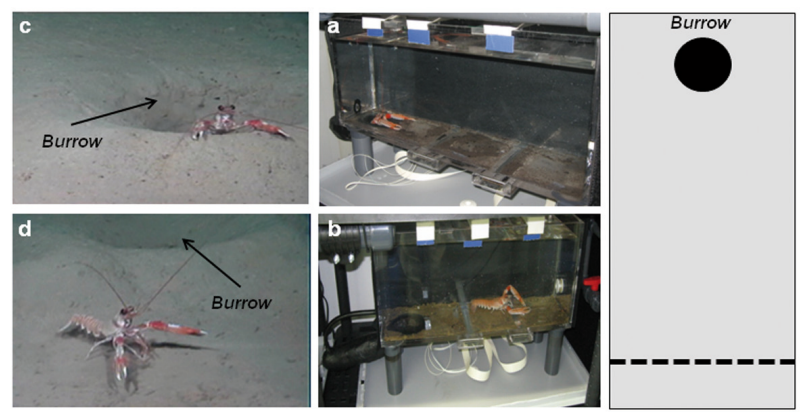

FIG. 1. - A schematic representation of the actograph is presented (right side) together with pictures of the actograph in the laboratory where Nephrops is at the burrow entrance (a) and engaged in full excursion out of the burrow (b). The dashed line (right side) represents the position of the IR beams at which the emergence behaviour is recorded. On the left side Nephrops norvegicus images depict behaviour of an individual at $665 \mathrm{~m}$ depth during the UE funded EUROLEON survey by ROV in the western Mediterranean (curtsey of Prof. M. Canals, University of Barcelona; Dr. J.B. Company, ICM-CSIC). c, at the burrow entrance; d, during an excursion away from the burrow.

Data were binned by $10 \mathrm{~min}$, and the occurrence of significant periodicity $(p<0.05)$ was determined using the Sokolove-Bushell periodogram (Sokolove and Bushell 1978). Time series were screened between 600 and 1600 min (i.e. between 10 and $27 \mathrm{~h}$ ). Arrhythmic individuals were those with no significant peaks and were excluded from the following analysis.

Waveform analysis was conducted by subdividing time series into 24-h sub-segments. An average 24-h activity profile (representative of the 11-day trial) was calculated for each animal by averaging all sub-segment values at the corresponding $10 \mathrm{~min}$. The resulting curve was plotted with the standard error of the mean (SEM), and the midline estimating statistic of rhythm (MESOR) was represented as a horizontal threshold in
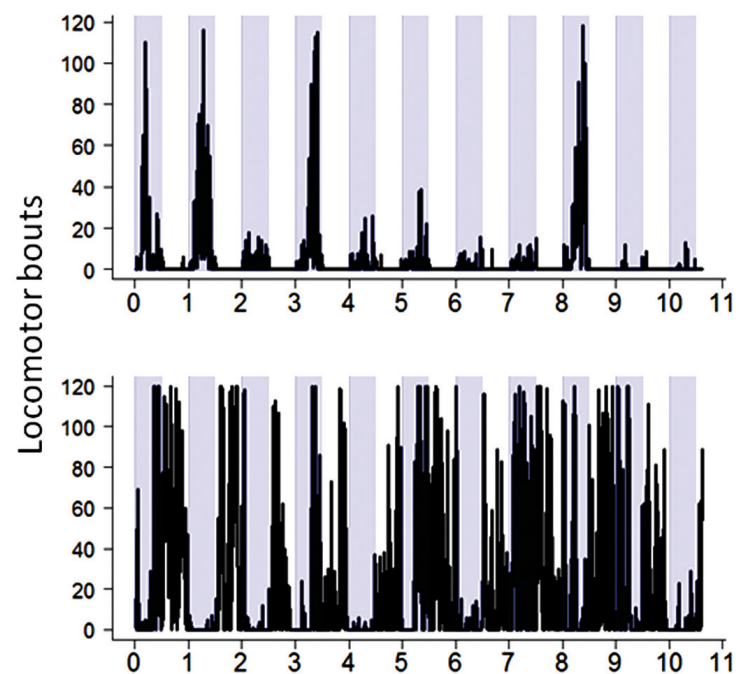

FIG. 2. - The row time series of four of our most representative animals showing the inter-individual variability observed at the first screening of data. Grey areas represent the darkness hours
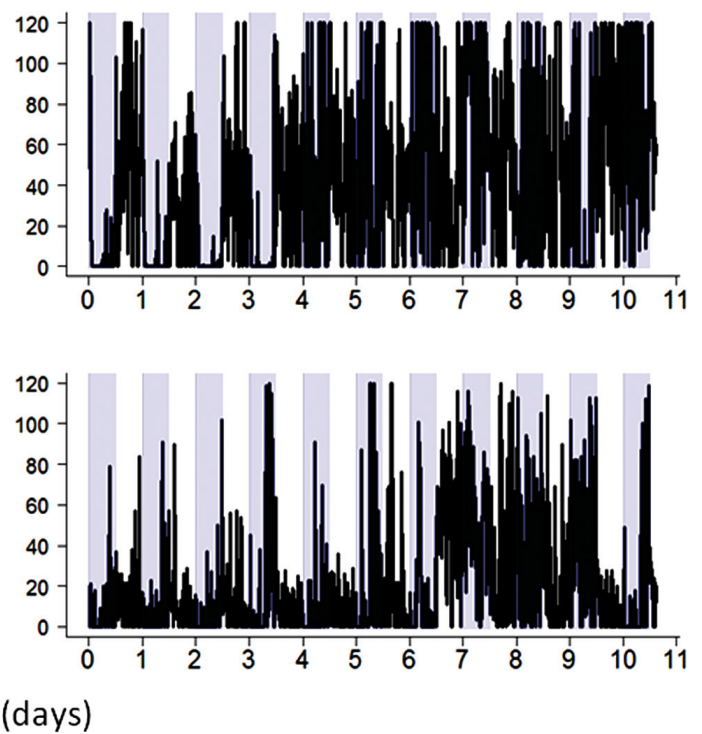

waveform plots. Only values above the MESOR constituted significant activity (adapted from Hammond and Naylor 1977). Finally, the phase was estimated by calculating the per cent area (A\%) under the waveform curve in relation to the per cent time $(\mathrm{t} \%)$. This parameter allows the activity concentration to be accurately estimated in a determined time interval.

Animals were grouped by their highest phase value (A\%/t\%) within four temporal intervals: $i$ ) dawn (06:0008:00); ii) dusk (18:00-20:00); iii) day (08:00-18:00); and iv) night (20:00-06:00). Average waveforms for each group, including the arrhythmic one, were plotted to obtain a single representative 24-h curve. All time series analyses were carried out with the El Temps software (www.el-temps.com). Chi-square tests $(p<0.05)$ were used to determine whether the detected rhythmic patterns were differentially distributed between sexes or experimental replicates.

\section{RESULTS}

We reported appreciable levels of burrow emergence behaviour according to the imposed monochromatic blue LD cycle. We selected four representative animals to show the observed variability in such behaviour (Fig. 2).

Periodogram analysis detected the occurrence of significant diel locomotor patterns in 45 animals (87\%; with an average period of $24.17 \pm 0.24$ ). The seven remaining animals (13\%) were classified as arrhythmic. The clustering of rhythmic animals according to the timing of the highest A\%/t \% ratio allowed the following grouping: i) 28 at dusk; ii) 2 at dawn; iii) 10 nocturnal; and iv) 5 diurnal (Fig. 3; Table 1). The chi-square tests showed that the five recognized temporal patterns (dusk, dawn, nocturnal, diurnal, and arrhythmic) were

Time (days) 


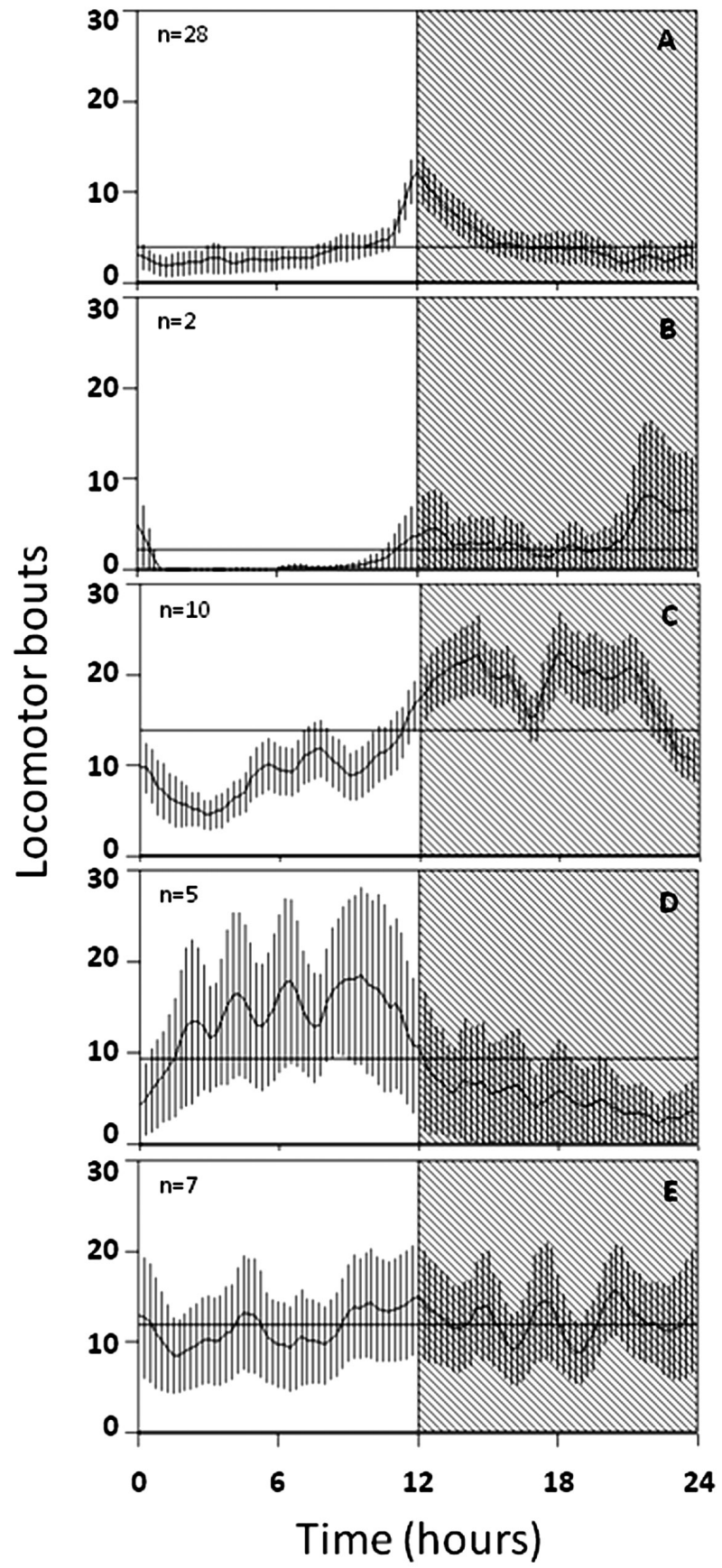

FIG. 3. - Average waveforms representing the rhythmic emergence patterns for Nephrops norvegicus out of the burrow. A, dusk $(\mathrm{n}=28)$; $\mathrm{B}$, dawn $(\mathrm{n}=2) ; C$, nocturnal $(\mathrm{n}=10)$; $\mathrm{D}$, diurnal $(\mathrm{n}=5)$; E, arrhythmic $(n=7)$. The horizontal line represents the MESOR. Vertical lines represent the standard error of the mean. Shadowed areas represent dark hours

not differently distributed between sexes $\left(\chi^{2}=8.05\right.$; d.f. $=4 ; p=0.09)$ or experimental replicates $\left(\chi^{2}=18.05\right.$; d.f. $=16 ; p=0.32$ ).

Laboratory data were then plotted together with the shelf-catch pattern obtained during a survey of continuous trawling (1- or 2-h frequency of trawl repetition) over four days (Fig. 4) in the same area from which the animals were sampled (Aguzzi et al. 2003). The
TABle 1. - Proportion of rhythmic (significant peaks in periodogram analysis) and arrhythmic (no significant peaks in periodogram analysis) Nephrops norvegicus. Animals are classified as dusk, dawn, nocturnal, and diurnal respect to the timing of the highest value of $\mathrm{A} \% / \mathrm{t} \%$ observed during waveform analysis (see text for further details)

\begin{tabular}{lccc}
\hline & $\mathrm{N}$ & Phase & Percentage \\
\hline Arrhytmic & $7 / 52$ & --- & $13 \%$ \\
Dusk & $28 / 52$ & $18: 00-20: 00$ & $54 \%$ \\
Dawn & $2 / 52$ & $06: 00-08: 00$ & $4 \%$ \\
Nocturnal & $10 / 52$ & $20: 00-06: 00$ & $19 \%$ \\
Diurnal & $5 / 52$ & $08: 00-18: 00$ & $10 \%$ \\
\hline
\end{tabular}

comparison was performed by plotting a curve depicting the number of animals with a rhythmic pattern for each data point of the catch pattern. Waveform analysis indicated that 28 out of 45 animals showed an average activity peak out of the burrow towards dusk (see Fig. 3A). These laboratory animals are likely similar to the animals that generate the first event of massive emergence reported in the field through the temporally scheduled trawling. Interestingly, only 2 of 45 animals exhibited peak emergence behaviour at the simulated dawn (see Fig. 3B), while the field catch pattern always showed two peaks of captures (at dusk and dawn) (see Fig. 4). Other animals (10 out of 45) showed a fully nocturnal emergence (see Fig. 3C). Animals exhibiting a nocturnal rhythm in the laboratory may account for the proportion of those captured any time at night; in fact, the field catch pattern never dropped to zero during that time (see Fig. 4). We also reported 5 out of 45 rhythmic individuals with a diurnal emergence pattern (see Fig. 3D). Catches dropped almost to zero only at midday. Our laboratory individuals may reflect the category of animals that emerge at daytime in the field. Finally, animals with an arrhythmic waveform pattern (see Fig. 3E) could reflect the category of animals in the field that are always available to trawling.

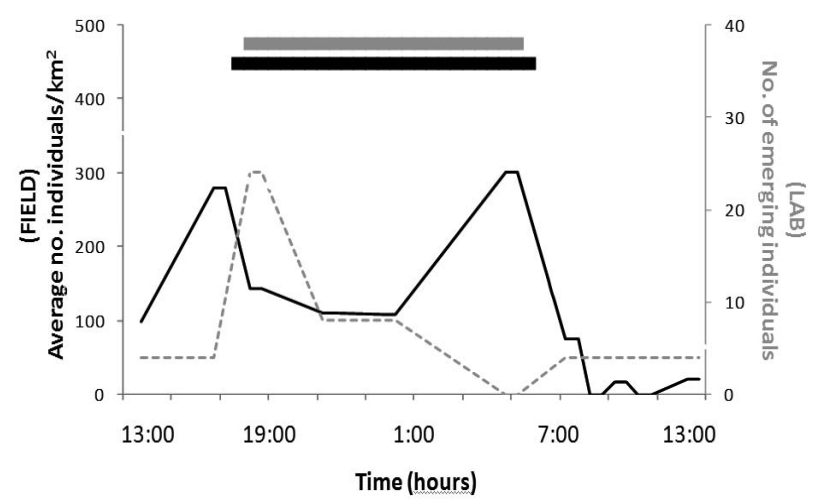

FIG. 4. - Comparison of catch pattern (adapted from Aguzzi et al. 2003) and laboratory results obtained in this study. Each average data point of the catch pattern was used to report the number of animals at the corresponding timing in the lab. Field (black line): average density of $N$. norvegicus (no. individuals per $\mathrm{km}^{-2}$ ) sampled during four days of continuous trawling at $100 \mathrm{~m}$ depth on the continental shelf during the month of October. Laboratory (grey dotted line) timing of emergence out of the burrow (no. of emerging individuals) evaluated by waveform analysis. Dark bar represents night in the field; grey bar represents dark hours in the laboratory. 


\section{DISCUSSION}

In this study, our objective was to quantify the interindividual variability of rhythmic burrow emergence in $N$. norvegicus exposed to blue light intensity that simulates the photic conditions of shelf populations. Specifically, we compared laboratory results with catch patterns in the same area from which the animals were sampled. We found that more animals emerged at simulated dusk than at dawn (54\% vs 4\%), while shelfcatch patterns always showed two equally pronounced crepuscular peaks (Aguzzi et al. 2003). Further, we detected a non-negligible proportion of arrhythmic individuals (13\%), indicating that such a behavioural pattern might also exist in the wild.

Our laboratory animals exhibited a high degree of inter-individual variability in burrow emergence timing (including arrhythmia). This variability may account for a lower synchronism in burrow emergence within populations than was previously inferred by analysing catch patterns. In fact, a temporally variable emergence pattern has been directly observed in the field by water imaging and scuba diving, where animals were seldom seen away from their burrows in a synchronous fashion (DAFS 1966, Rice and Chapman 1971, Chapman et al. 1975). In this framework, our data suggest that $N$. norvegicus possess a circadian system that is controlled not only by blue light stimuli but also by other factors in the field that modulate and adjust the timing of burrow emergence (Chiesa et al. 2010, CastilloRuiz et al. 2012, Hut et al. 2012). Aguzzi et al. (2011) proposed that Nephrops' circadian system is based on a population of coupled oscillators. Their decoupling may account for modifications in burrow emergence behaviour at different shelf and slope depths, as well as for inter-variability and arrhythmia at the same depth. Animals do not perform bathymetric migrations along the continental margin, and their settling likely occurs equally among shelves and slopes (Powell and Eriksson 2013). Therefore, lobsters must be able to cope with markedly different ecological contexts, including different light conditions (Farmer 1975, Bell et al. 2006, Aguzzi and Sardà 2008, Johnson et al. 2013). The reported laboratory inter-individual variability in emergence behaviour may represent an evolutionarily adaptive strategy that allows the species to colonize muddy sea bottom areas across a wide range of depths and latitudes. Indeed, other marine species, such as the isopod Excirolana chiltoni (Enright 1976), the polychaete Nereis virens (Last et al. 2009) and the oyster Crassostrea gigas (Mat et al. 2012) show some degree of flexibility in the regulation of their behavioural rhythms.

Only two animals in our laboratory tests exhibited burrow emergence at dawn (see Fig. 3b). A differential response to dusk and dawn burrow emergence was already observed in previous studies that used a different light spectrum $(530 \mathrm{~nm})$ and fewer animals (Arechiga and Atkinson 1975, Atkinson and Naylor 1976, Ham- mond and Naylor 1977). Taken together, these observations raise an important question: what ecological factor not represented in the laboratory induces the bimodal burrow emergence behaviour in shelf populations inferred from temporally scheduled trawling? Chapman et al. (1972) proposed the "optimum light intensity concept" to emphasize that sunlight is the most important cue determining the emergence behaviour of $N$. norvegicus at different depths. The results presented here partially agree with this scenario but do not provide an explanation for the lack of emerging animals during the simulated dawn. Aguzzi and Sardà (2008) hypothesized that shelf animals emerge twice a day. The first emergence behaviour peak occurs at sunset (entrained by the falling of light intensity) and allows them to feed under favourable conditions (i.e. abundant prey and limited predators). Animals that fail to obtain food prolong their emergence over the whole night. This behaviour would be responsible for generating the first peak in catches at dusk and the following low (but still present) catchability over the whole night (see Fig. 4). According to the authors, at dawn, animals that previously retired after dusk (those that had succeeded in food retrieval) would join those still engaged in emergence, generating the second peak. Thus, this second peak in emergence behaviour could be induced by an additional event of food search under optimal light conditions at sunrise, as indicated by the $\%$ of empty stomachs (Oakley 1979, Aguzzi et al. 2005).

In our experiments, the animals were never fed. The absence of food provision may have suppressed the occurrence of a second emergence event at simulated sunrise. Satiety can inhibit locomotor behaviour in the crayfish Procambarus clarkii (Fernandéz de Miguel and Aréchiga 1994), but data regarding feeding effects on the burrow emergence rhythmic behaviour are scarce. Experiments with ad libitum feeding protocols could reveal whether the dawn peak of emergence is food-related. However, measuring the provision of food is not an easy task to accomplish in the laboratory. Nephrops usually retire to the burrow once they have obtained a piece of food, and the time before this food is totally consumed is unknown (personal observation). Sardà and Valladares (1990) recommended that a meal should be provided every $24 \mathrm{~h}$ according to the time required for complete gastric evacuation. Therefore, investigating the effects of ad libitum feeding protocols on the rhythmic emergence behaviour of Nephrops is problematic within this experimental framework.

In the laboratory, arrhythmic animals have always been dismissed as atypical due to stress (e.g. Aguzzi et al. 2004b), but these animals may represent a consistent proportion of individuals within natural populations. These individuals possess emergence behaviour that is more random and can therefore be captured throughout the day (see Fig. 3E). In fact, shelf catches at nighttime and daytime never drop to zero (with the exception of midday). However, we cannot refute the hypothesis that arrhythmia may occur in our labora- 
tory animals due to the disruption of circadian system pathways; laboratory conditions and manipulation may disrupt behavioural activity (Calisi and Bentley 2009). Nonetheless, we interpret the occurrence of arrhythmia as additional proof of the plasticity and liability of the Nephrops circadian system (Frenkel and Ceriani 2011).

In conclusion, the ultimate aim of chronobiology is to understand how representative laboratory behaviour is of natural behaviour. Efforts should focus on the ecological and adaptive meanings of circadian rhythms and relating the reported inter-individual variability among individuals to population patterns (Menaker 2006). This study presents our first efforts to address such questions using Nephrops, a species at the centre of attention of many European researchers (Johnson and Johnson 2013). We found the presence of variable dusk but not dawn burrow emergence behaviour. Our future research goals are to identify which factors may exogenously induce such behavioural variability.

\section{ACKNOWLEDGEMENTS}

This work was completed during a fellowship at the Marine Science Institute, promoted by Coop. Cypraea and supported by Italia Lavoro Spa. V. Sbragaglia is now a Predoctoral Fellow within the Fomación Personal Investigador (FPI) scheme (MICINN). J. Aguzzi is a Postdoctoral Fellow within the Ramón y Cajal Program (MICINN). The data presented in this work were obtained during the RITFIM project (CTM201016274), which was funded by the Ministry of Science and Innovation (MICINN). We are grateful to Dr. E. Gaten and Dr. K. Last who improved the manuscript, and also to Dr. Stefano Cerioni for his support.

\section{REFERENCES}

Aguzzi J., Sardà F. 2008. A history of recent advancements on Nephrops norvegicus behavioral and physiological rhythms. Rev. Fish. Biol. Fisheries 18: 235-48.

Aguzzi J., Bahamon N. 2009. Modeled day-night biases in decapod assessment by bottom trawling survey. Fish. Res. 100: 274-280.

Aguzzi J., Company J.B. 2010. Chronobiology of deep-water decapod crustaceans on continental margins. Adv. Mar. Biol. 58: 155-225.

Aguzzi J., Sardà F., Abelló P., Company J.B., Rotlland G. 2003. Diel and seasonal patterns of Nephrops norvegicus (Decapoda: Nephropidae) catchability in the western Mediterranean. Mar. Ecol. Prog. Ser. 258: 201-211.

Aguzzi J., Company J.B., Abelló P. 2004a. Locomotor activity rhythms of continental slope Nephrops norvegicus (Decapoda: Nephropidae). J. Crustac. Biol. 24: 282-290.

Aguzzi J., Company J.B., Sardà F. 2004b. Feeding activity rhythm of Nephrops norvegicus of the western Mediterranean shelf and slope grounds. Mar. Biol. 144: 463-472.

Aguzzi J., Chiesa J., Abelló P., Diez-Noguera A. 2005. Temporal modification in cardiac rhythmicity of Nephrops norvegicus (Crustacea: Decapoda) in relation to trawl capture stress. Sci. Mar. 69: 369-374.

Aguzzi J., Sarriá D., García J.A., Del Rio J., Sardà F., Manuel A. 2008. A new tracking system for the measurement of diel locomotor rhythms in the Norway lobster, Nephrops norvegicus (L.). J. Neurosci. Met. 173: 215-224.

Aguzzi J., Costa C., Menesatti P., García J.A., Sardà F. 2009. Monochromatic blue light entrains diel activity cycles in the Norway lobster, Nephrops norvegicus (L.) as measured by automated video-image analysis. Sci. Mar. 73: 773-783.

Aguzzi J., Company J.B., Costa C., Menesatti P., Bahamon N., Sardà, F. 2011. Activity rhythms in the deep-sea crustacean: Chronobiological challenges and potential technological scenarios. Front. Biosci. 16: 131-150.

Aréchiga H., Atkinson R.J.A. 1975. The eye and some effects of light on locomotor activity of Nephrops norvegicus. Mar. Biol. 32: $63-76$.

Atkinson R.J.A., Naylor E. 1976. An endogenous activity rhythm and the rhythmicity of catches of Nephrops norvegicus (L.). J. Exp. Mar. Biol. Ecol. 25: 95-108.

Bell M.C., Redant F., Tuck I. 2006. Nephrops species. In: Phillips B.F. (ed.) Lobsters: biology, management, aquaculture and fisheries. Blackwell Publishing, Oxford, pp. 412-461.

Bloch G., Robinson G.E. 2001. Chronobiology. Reversal of honey bee behavioural rhythms. Nature 410: 1048.

Calisi R.M., Bentley G.E. 2009. Lab and field experiment: are they the same animal? Horm. Behav. 56: 1-10.

Castillo-Ruiz A., Paul M.J., Schwartz W.J. 2012. In search of a temporal niche: social interactions. In: Kalsbeek A., Merrow M., Roenneberg T., Foster R.G. (eds), The neurobiology of circadian timing. Prog. Brain. Res. 199: 267-279.

Chapman C.J., Rice A.L. 1971. Some direct observations on the ecology and behaviour of the Norway lobster, Nephrops norvegicus. Mar. Biol. 10: 321-329.

Chapman C.J., Howard F.G. 1979. Field observations on the emergence rhythm of the Norway Lobster Nephrops norvegicus, using different methods. Mar. Biol. 5: 157-165.

Chapman C.J., Johnstone A.D.F., Rice A.L. 1975. The behaviour and ecology of the Norway lobster, Nephrops norvegicus (L.). In: Barnes H. (ed.), Proceedings of the 9th European Marine Biological Symposium. Aberdeen University Press, Aberdeen, pp. 59-74.

Chapman C.J., Priestley R., Robertson H. 1972. Observations on the diurnal activity of the Norway lobster, Nephrops norvegicus (L.). ICES Shellfish and benthos committee, K: 20 pp. 18.

Chiesa J.J., Aguzzi J., García J.A., Sardà F., De la Iglesia H.O. 2010. Light Intensity Determines Temporal Niche Switching of Behavioral Activity in Deep-Water Nephrops norvegicus (Crustacea: Decapoda). J. Biol. Rhythms 25: 277-287.

Department of Agriculture and Fisheries for Scotland 1966. Nephrops (Norway lobsters).

Enright J.T. 1976. Plasticity in an isopod's clockworks: shaking shapes form and affects phase and frequency. J. Comp. Physiol. 107: 13-37.

Farmer A.S.D. 1975. Synopsis of biological data on Norway lobster Nephrops norvegicus (Linneo, 1758). FAO FIRS/S 112.

Fanjul-Moles M.L., Escamilla-Chimal E.G., Gloria-Soria A., Hernández-Herrera G. 2005. The crayfish Procambarus clarkii CRY shows daily and circadian variation. J. Exp. Biol. 207: 1453-1460.

Fernandéz de Miguel F., Aréchiga H. 1994. Circadian locomotor activity and its entrainment by food in the crayfish Procambarus clarkii. J. Exp. Biol. 190: 9-21.

Frenkel L., Ceriani M.F. 2011. Circadian plasticity: from structure to behaviour. Int. Rev. Neurobiol. 99: 107-137.

Froglia C. 1972. Osservazioni sulle variazioni di cattura dello scampo Nephrops norvegicus (L.) in riferimento all'etologia ed alla biologia della specie. Quad. Lab. Tecnol. Pesca Ancona 1: 83-99.

Gaten E. 1988. Light induced damage to the dioptric apparatus of Nephrops norvegicus (L.) and the quantitative assessment of the damage. Mar. Behav. Physiol. 13: 169-83.

Gaten E., Shelton P.M.J., Chapman C.J., Shanks A.M. 1990. Depth related variation in the structure and functioning of the compound eye of the Norway lobster Nephrops norvegicus. J. Mar. Biol. Assoc. UK 70: 343-55.

Gaten E., Moss S., Johnson M.L. 2013. The reniform reflecting superposition compound eyes of Nephrops norvegicus: optics, susceptibility to light-induced damage, electrophysiology and a ray tracing model. In: Johnson M., Johnson M. (eds), The ecology and biology of Nephrops norvegicus. Adv. Mar. Biol. 64: 107-148.

Hammond R.D., Naylor E. 1977. Effects of dusk and dawn on locomotor activity rhythms in the Norway lobster Nephrops norvegicus. Mar. Biol. 39: 253-260.

Hankins M.W., Peirson S.N., Foster R.G. 2008. Melanopsin: an exciting photopigment. Trends in neurosci. 31: 27-36. 
Hillis J.P. 1971. Effects of light on Nephrops catches. ICES CM K:03.

Hut R.A., Kronfeld-Schor N., Van der Vinne V., De la Iglesia H. 2012. In search of a temporal niche: environmental factors. In: Kalsbeek A, Merrow M, Roenneberg T, Foster RG (eds), The neurobiology of circadian timing. Prog. Brain. Res. 304: 281-304.

Jerlov N.G. 1968. Optical oceanography. Elsevier, Amsterdam, pp 194.

Johnson M., Lordan C., Power A.M. 2013. Habitat and ecology of Nephrops norvegicus. In: Johnson M., Johnson M. (eds), The ecology and biology of Nephrops norvegicus. Adv. Mar. Biol. 64: $27-63$.

Johnson M., Johnson M. 2013. The ecology and biology of Nephrops norvegicus. Adv. Mar. Biol. 64.

Katoh E., Sbragaglia V., Aguzzi J., Breithaupt T. 2013. Sensory biology and behaviour of Nephrops norvegicus. In: Johnson M., Johnson M. (eds), The ecology and biology of Nephrops norvegicus. Adv. Mar. Biol. 64: 65-106.

Last K.S., Bailhache T., Kramer C., Kyriacou C.P., Rosato E., Olive P.J.W. 2009. Tidal, daily, and lunar-day activity cycles in the marine polychaete Nereis virens. Chronobiol. Int. 26:167-183.

Main J., Sangster G.I. 1985. The behaviour of the Norway lobster Nephrops norvegicus (L.), during trawling. Scottish Fish. Res. Rep. 34: 1-23.

Mat A., Massabuau J.C., Ciret P., Tran D. 2012. Evidence for a plastic dual circadian rhythm in the oyster Crassostrea gigas.
Chronobiol. Int. 29: 857-867.

Menaker M. 2006. Circadian organization in the real world. Proc. Natl. Acad. Sci. 103: 3015-3016.

Oakley S.G. 1979. Diurnal and seasonal changes in the timing of peak catches of Nephrops norvegicus reflecting changes in behaviour. In: Naylor E., Hartnoll R.G. (eds), Cyclical phenomena in marine plants and animals. Europ. Mar. Biol. Symp. 13. Pergamon Press, Oxford, pp. 367-374.

Powell A., Eriksson S.P. 2013. Reproduction: life cycle, larvae and larviculture. In: Johnson M., Johnson M. (eds), The ecology and biology of Nephrops norvegicus. Adv. Mar. Biol. 64: 201-245.

Rice A.L., Chapman C.J. 1971. Observations on the burrows and burrowing behaviour of two mud-dwelling decapod crustaceans, Nephrops norvegicus and Goneplax rhomboides. Mar. Biol. 10: 330-342.

Sardá F., Valladares F.J. 1990. Gastric evacuation of different foods by Nephrops norvegicus (Crustacea: Decapoda) and estimation of soft tissue ingested, maximum food intake and cannibalism in captivity. Mar. Biol. 104: 25-30.

Sokolove P.G., Bushell W.N. 1978. The chi square periodogram: its utility for analysis of circadian rhythms. J. Theor. Biol. 72: 131-160.

Scient. ed.: C. Zeng.

Received Juny 4, 2013. Accepted October 7, 2013.

Published online October 28, 2013. 